\title{
O Apóstolo da Paz
}

De todos os títulos com que se enobrecem os feitos, a ação e a figura singular de Rio Branco, - e êles se contam por inúmeros, - o mais legítimo, o mais belo de todos, aquele que, justamente, o glorifica e o perpetuará, indefinidamente, na memória e reconhecimento da posteridade, é, sem contestação, o de Apóstolo da Paz.

O pendor que, desde cedo, demonstrara pelos assuntos históricos; sua atuação, ao lado do Visconde, seu pai, ao pleitear na tribuna e na imprensa, pela vitória da Lei do Ventre Livre; as Missões e os Tratados de Arbitramento em que se houve com a dignidade de um paladino; a orientação por êle infundida à diplomacia brasileira, tudo isso se resume, afinal, no amor da Pátria, traço evidente de sua grande personalidade.

Sem êsse sentimento que era, nêle, o símbolo da pujança do espírito, a razão de ser da sua integridade espiritual e moral, de que se abeberara no lar onde nascera e se criara, predestinando-se à vida pública, as suas conquistas, por inigualáveis que tivessem sido, seriam efêmeras e transitórias. Irrompendo da penumbra para a glória, Rio Branco deveria conquistar, repentinemente; a admiração e o respeito dos seus patrícios, em virtude dessa intuição institiva com que os cidadãos predestinados se revelam à nítida compreensão das turbas.

E que o povo, sem que o pudesse explicar, justificando-se de sua própria admiração, pressentiu nêle o homem capaz de realizar as suas íntimas aspirações e transformou-o através da imaginação, na autêntica figura de um herói. Rara vez, na história política de uma nacionalidade, as classes sociais, em todos os seus matizes, prosseguindo por atalhos diferentes $\mathrm{e}$ insuspeitados, alcançariam ritmar seus anelos e aspirações, unindo-se, integrando-se, fraternizando-se num só pensamento e nos mesmos louvores, em tôrno de uma só personalidade. 
Essa unanimidade nós a conhecemos, ao tempo de Rio Branco, pelo milagre do seu gênio político, pela irradiação das virtudes cívicas de sua incomparável personalidade. E que à benemerência do seus feitos, aos anseios dos seus propósitos, à decisão e ideação permanentes, de um decidido programa de tranquilidade e prosperidade da Pátria e, por igual, da América, Rio Branco, - o extraordinário defensor do pacifismo sulamericano, - aliou sempre, sem desfalecimento, concientemente, a convicção profunda de que, somente pela força do Direito e da Justiça as nações se fortalecem no respeito de sua gente e crescem e se alteiam na admiração dos outros povos.

As fôrças armadas, no seu entender, e dêsse ponto de vista nos deu provas exuberantes e decisivas, mereceram também o seu carinho e preocupação as forças armadas deviam constituir o arnês inviolavel, diante do qual esbarrassem e esmorecessem os possiveis agressores da soberania nacional. Em dado momento de sua vida pública, Rio Branco, antevendo profeticamente o futuro, que é hoje a realidade dos nossos dias, preguntava a um diplomata sulamericano, referindo-se à integridade das Américas: "- Sabemos nós, por acaso, que surpresas nos reserva o futuro? Vastos são os nossos territórios deshabitados ... e não são poucos os cobiçados ..."

Sua conviç̧ão ao imaginar uma agressão estranjeira, no sentido de conquistas imperialistas, era a de que a América, como um só homem, conjugando suas fôrças, se erguesse, marchando lado a lado para o mesmo destino e para a mesma glória. Não estava e nunca esteve em seus propósitos isolar o Brasil dos demais povos do continente; sua aspiração, ao contrário disso, era irmaná-los, fraternizá-los à coesão dos mesmos sentimentos de liberdade e de independência. Esse foi sempre o seu pensamento político.

Retornando à Pátria, depois de longo afastamento, errando, peregrinando de país em país, os louros das vitórias que conquistara longe de sua terra, refloriram e se multiplicaram em outros tantos triunfos, através dos quais se consagraria na admiração e na popularidade dos seus patrícios. Poucos homens, a exemplo de Rio Branco, - não só na nossa, mas na observação dos estranjeiros que conviviam conosco, desfrutaram, em nosso país, de tamanha e permanente popularidade.

O povo o aplaudia quando, ainda de longe, das terras ignotas em que vivia, projetava sobre a Pátria o esplendor de suas vitórias. E essa admiração, ao invés de esmorecer à proximidade e ao contacto do homem, assumiu depois, nas horas de sua agonia e no momento culminante do seu trespasse, as proporções de' uma calamidade coletiva, e, por fim, de luto 
nacional, em que as próprias cousas da cidade do seu berço e de sua glória se associaram, justificando as homenagens que lhe deviamos.

"E quando o grande Brasileiro seguiu para aderradeira morada, - escreveu um de seus panegiristas, - foi todo o povo que o levou numa dessas marés irresistíveis que mudam os préstitos fúnebres em cortejos triunfais." E que o "povo o amava, - prosseguia o escritor, - e o ama, porque sente que havia entre a sua alma humilde e a alma radiosa do seu superhomem um sentimento comum que, apesar de todas as distâncias, as irmanava: o amor da Pátria".

$O$ povo o respeitava e bemqueria, pressentindo, irresistivelmente, que no coração do grande homem que dilatara os lindes de nossa terra, enfrentando pleitos renhidos e difíceis, pulsava e floria o mesmo sentimento do amor da Pátria, profundo e imortal, à atração do qual os humildes e anônimos se fraternizan e confundem, irmanando-se às personalidades mais eminentes perante o reconhecimento da História.

$O$ historiador e o geógrafo que, paciente e amorosamente traçava e reconstituia com as suas próprias mãos, a configuração de nossas balizas territoriais, estudando velhas crônicas, folheando mapas anacrônicos, caminhando, em imaginação, por vetústos roteiros, sentia, aspirava em todos êles, - dêsde os tempos remotos da descoberta, da conquista e da colonização, - o delicioso e inconfundivel perfume da terra virgem e privilegiada onde nascera. $E$ ao prestígio dêsse sentimento estampou no escudo de suas aspirações o lema definitivo do programa de sua vida, fundindo assim, no bronze da perene inmortalidade, o distintivo do Ubique patriae memor, o mais legítimo do seus títulos de cidadão. Nessa divisa se estampam e revelam, à luz meridiana da posteridade, o espêtho de sua alma, a coloração inconfundivel do seu patriotismo construtor, em uma palavra. a verônica estelar do seu excelente espírito.

A suprema aspiração de Rio Branco, revelada na constância de sua grande obra, era a prosperidade do seu povo, a dignidade de sua terra, sem malquerenças, sem invejas nem ódios mesquinhos para com as demais naçōes do Continente. O seu sonho maior pode ser sintetizado na confraternização dos povos americanos, ou, como êle mesmo o proclamara na Terceira Conferência Internacional Americana, por estas expressóes textuais: "Os nossos votos são porque desta Conferência resulte, confirmada e definida em atos e medidas práticas de interêsse comum, auspiciosa segurança de que não estão longe os tempos da verdadeira confraternidade internacional. Já é dela um penhor êsse ânimo geral de procurar meios de 28 
conciliar interesses opostos ou aparentemente contrários, encaminhando-os em seguida para o mesmo serviço do ideal ao progresso na paz."

Assim pensava Rio Branco, e nesse mesmo ritmo de pensamento estava firmado o programa da política do Brasil, porque, como êle mesmo o assinalara: "O dever do estadista, e de todos os homens de verdadeiro śenso político, é combater as propagandas de ódios e rivalidades internacionais.

"Nem população densa, nem dureza de vida material, podem tornar o Brasil suspeito aos povos que ocupam êste nosso continente da América. Repúblicas limítrofes, a todas as nações americanas só desejamos paz, iniciativas inteligentes e trabalhos fecundos para que, prosperando e engradecendo-se, nos sirvam de exemplo e estímulo à nossa atividade pacífica, como a nossa grande e gloriosa irmã do norte, promotora desta Conferência" . .

Esse o espírito tutelar, invariavel, da politica internacional brasileira, nascida no Império, prosseguida na República, e que, para glória nossa, se mantém e perpetúa em nossos dias, nas lides diplomáticas do Itamaratí, na irrevogável decisão de cumprir, à risca, as tradições pacifistas do nosso país. Dando o exemplo dessa paz permanente e pela qual se fortalecera na confiança das nações do Continente, o Brasil atingiu, sob Rio Branco, o esplendor de que hoje e sempre nos orgulharemos.

Razões inestimáveis assistiam ao supremo magistrado que ora dirige os destinos da nossa Pátria, ao proclamar em síntese, os feitos de Rio Branco: "Ele, apontando para o mapa do Brasil, poderá repetir" a frase de Tácito deante das planícies de Roma - eis o meu poema."

O Senhor Getúlio Vargas interpretou, fielmente, nessa frase, o pensamento do Brasil. Esse poema de infinita e maravilhosa grandeza, Rio Branco o escreveu, à semelhança do grande Anchieta, no coração da própria terra, retificando-lhe as fronteiras, dissipando remotas divergências, aplainando, pacificamente, terríveis dificultades, mostrando, enfim, àqueles que se decidiram competir conosco, a legitimidade do nosso bom direito assegurado em velhos mapas em que se estampava a fisiografia da terra que herdáramos dos primitivos conquistadores.

Para adquirir essa convicção inabalável, consumiu Rio Branco uma existência inteira, e, longe da Pátria, nunca lhe esteve mais próximo e dentro do seu destino, senão, quando, isolado no seu pôsto de Cônsul, ou diante de côrtes e magistrados estranjeiros, revidava aos seus opositores, provando com documentos irrespondíveis, legítimos e claros, o direito do Brasil, de que se fez o incerprete sempre vitorioso!

Sua armadura de paladino de causas justas e dignas tornou-se inviolável e invencível, e ao acrescentar à Pátria os milhões de quilomêtros 
quadrados que a reintegravam na sua grandeza, alinhando nessas fronteiras longinquas, os invisíveis mas irredutíveis soldados do Direito e da Justiça, Rio Branco cresceu, avultou na admiração dos seus patrícios, imortalizando-se na glorificação com que o Brasil há-de celebrá-lo na eternidade dos seus dias de nação livre e independente.

Ao norte, ao sul, ao centro, por todo êste vasto território que abrange um têrço da configuração geográfica da América, a memória, os feitos, as vitórias e triunfos que conquistamos por intermédio da ação e do pensamento do grande paladino, estarão sempre presentes na alma e no reconhecimento de seu povo. Sua presença, materializada nas obras que o engrandeceram, nos exemplos de sabedoria com que nos edificou no respeito próprio e alheio, valerá, através dos tempos, para orgulho do Brasil, como padrão legítimo do nosso destino, perante os povos do Continente.

Poderemos dizer hoje, e aspiramos repetir no futuro, com o mesmo fervor e igual sentimento de anelos pacifistas, as palavras modelares com que Rio Branco se dirigiu aos representantes estranjeiros, os quais, depois de assistirem aos trabalhos do Congresso Internacional de Históita Americana, não teriam dúvida em afirmar: "... Que viram uma bela terra habitada por um bom povo; terra generosa e farta, povo laborioso e manso como as colméias em que sobra mel. Não há aqui quem alimente inveja contra os povos vizinhos, porque tudo esperamos no futuro; nem ódios, porque nada sofremos dêles no passado. Um grande sentimento nos anima: o de progredir rapidamente sem quebra das nossas tradições de liberalismo e sem ofensa dos direitos alheios"...

A essa voz suave, mansa, profunda e eloquente, do digno varâo, responderá a própria voz da Pátria, murmurando-lhe à beira do monumento onde repousam suas cinsas sagradas, a nênia do eterno reconhecimento, com que a poesia glorifica os heróis de sua estirpe:

Tu cantarás na voz dos sinos, nas charrúas, no esto da multidão, no tumultuar das ruas, no clamor do trabalho e nos hinos da paz! $E$, subjugando o olvido, através das idades ... dentro do coração da Pátria viverás!

Phocion Serpa 
